\title{
IMPLICATIONS OF THE COVID-19 CRISIS FOR THE SHARING ECONOMY IN TOURISM: THE CASE OF AIRBNB IN THE CZECH REPUBLIC
}

\author{
Vendula Fialova ${ }^{1, a, *}$ and Ivanka Vasenska ${ }^{2, b}$ \\ ${ }^{1}$ Institute of Entrepreneurship and Marketing, The College of Entrepreneurship and Law, Vltavská \\ 585/14, 15000 Praha 5, Czech Republic \\ ${ }^{2}$ South-West University, Faculty of Economics, Department of Tourism, 60 Ivan Mihaylov, 2700 \\ Blagoevgrad, Bulgaria \\ avendula.fialova@vspp.cz, bivankav@swu.bg \\ *Corresponding author
}

Cite as: Fialova, V, Vasenska, I. (2020). Implications of the COVID-19 crisis for the sharing economy in tourism: The case of Airbnb in the Czech Republic, Ekonomicko-manazerske spektrum, 14(2), 78-89.

Available at: dx.doi.org/10.26552/ems.2020.2.78-89.

Received: 26 June 2020; Received in revised form: 30 July 2020; Accepted: 2 October 2020; Available online: 25 November 2020

\begin{abstract}
The concept of the sharing economy is spreading all over the world. From car rides to home sharing to tool rentals, the sharing economy offers all this and much more. Its business models are mediated through digital platforms that allow for a more accurate real-time measurement of spare capacities and can dynamically connect these capacities to those who need them; an example of such platform is Airbnb. Currently, international tourism has been completely paralyzed, and tourists around the world have been canceling their reservations. As of mid-March 2020, this applies to all customers worldwide. Property owners thus lost their sources of income for the coming weeks and the effects have been especially harsh for landlords using the Airbnb portal. In Czech Republic, most landlords using the Airbnb platform are in Bratislava, where less than a thousand properties are on offer. In other cities, the rental offer is more restricted. This research paper examines the impact of Covid-19 on occupancy of vacation rentals offered via Airbnb, by comparing and analyzing the expected and actual numbers of guests. The introduction outlines the theoretical approaches to the sharing economy and the way the Airbnb platform works. In the methodology section, a one-way ANOVA is described and applied. The results are followed by comparison of expectations and reality, discussion, and conclusions.
\end{abstract}

Keywords: shared economy; Airbnb; accommodation

JEL Classification: A11, L83, O31

\section{Introduction}

The concept of the sharing economy was here long before it has taken the form we know today. People borrowed property, rented homes, or offered their knowledge to others before the 21 st boom of sharing economy. We perceive the sharing economy today primarily as determined by the technologies that facilitate individual transactions between its users. The internet and smartphones, along with peer-to-peer transactions, have enabled the emergence of online platforms. These platforms have transformed the way people today can work, consume 
goods and services, or interact with each other. A breakthrough and a significant milestone the sharing economy was considered one of the driving forces behind the recovery of the global economy, confirming its growing role worldwide. It became widespread thanks to the internet and other means of digitization, and begun to be referred to as an alternative to the traditional economy (Vaughan and Daverio, 2016). It is particularly common in transport, tourism, housing, finance, education, energy, logistics, etc.

The essence of the sharing economy: share what you have with those who need it (Cheng, 2016; Edelman et al., 2017; Puschmann et al., 2016). This form is especially popular with those consumers who are looking for lower prices for various services of daily or frequent use; it offers new forms of self-employment with the possibility of generating additional income; and helps reduce unemployment and poverty.

The sharing economy's business models are mediated through digital platforms that allow for a more accurate real-time measurement of spare capacities and can dynamically connect these capacities to those who need them; an example of this is the rapidly growing Airbnb platform, where home owners share their properties with guests, with an impact not only on the hotel market but also on the private rental market (Krajcik et al., 2019). It connects the offer of available rooms and apartments with travelers looking for accommodation in a given location. Similarly, the Zipcar platform links the supply of available cars to local demand. People have been exchanging goods and services since time immemorial; today, the rise of digital devices makes it easier than ever to connect supply and demand.

Over the last few years, the term "sharing economy" has become extremely widespread. While many platforms live up to the original promise of the sharing economy-better use of resources, efficiency gains, and social capital building — other platforms appropriate the notion of "sharing" even when they do not represent a sharing economy model. This has given rise to the term "sharewashing" which can be understood as false presentation of platforms as instances of the sharing economy, the notable example being Uber. Ironically, the company does not consider itself a part of the sharing economy and has always presented itself as a technology and logistics platform that does not emphasize resource and community building. However, the media and the public do not seem to completely take this into account.

The sharing economy is characterized by transactions that favor access over ownership. We however should not see this model as a panacea; historically, people have kept wealth, such as their homes, in their possession.

Digital platforms enable individuals to offer accommodation more quickly and cheaply in the global marketplace without setting up a website or needing to formalize their business. Before the internet boom, offline peer-to-peer home-sharing and room rentals have existed for centuries. Today, digital platforms offer both market and payment systems to individuals who offer accommodation directly to end consumers without the need to build a website or collect payments directly.

Airbnb, Couchsurfing, HouseTrip, Windu and 9flats are some well-known accommodation organizations that rent rooms or entire residences (Belk, 2014). They outperform cheap hotels, motels, and luxury hotels (Guttentag and Smith, 2017), with Airbnb alone having served 30 million customers since its inception in 2008, even though it does not own a single room (Akbar and Tracogna, 2018). Many studies on accommodation in the sharing economy are indeed based on Airbnb. These studies examined price factors (Gutt and Herrmann, 2015); social functions and room sales (Lee et al., 2015); racism (B. G. Edelman and Geradin, 2015); functional characteristics (Chen and Xie, 2017a; Gibbs et al., 2018); host experience (Chen and Xie, 2017b; Wu et al., 2017); and professional and non-professional hosts (Li et al., 2016). For example, by warmly welcoming, providing basic food and drink, and satisfying guests' requests 
throughout their stay, hosts can provide a great experience for their guests (Camilleri and Neuhofer, 2017) and professional hosts are more likely to receive the "superhost" status (Gunter, 2018). In metropolitan areas, hosts tend to accept requests for high occupancy quickly (Karlsson et al., 2016), but some hosts lack the motivation and ability to manage their accommodation to maximize income (Liang et al., 2017). For remote Airbnb accommodation units, comfort and guarantee are crucial issues in measuring service quality (Priporas et al., 2017). Furthermore, close interaction between hosts and guests can lead to guests staying longer (Tussyadiah and Pesonen, 2016). However, there are mixed findings on whether such social interaction is valuable or not (Stollery and Jun, 2017). For many, the Airbnb brand is still unknown, although the platform has now been active in Czech Republic for some time. It is the world's most widely used portal providing short-term accommodation, used by tourists or people who are looking for short-term rentals (for a maximum of one month) and hotels do not suit them or are too expensive. Accommodation with owners is more convenient for some because they feel "at home" and have access to facilities that are not available in hotels. (Dudikova et al., 2010)

\subsection{Rentals via Airbnb}

The Airbnb portal is used mainly by people traveling abroad who are looking for a type of accommodation different than hotels or overpriced apartments. On average, rental prices on Airbnb are $30-50 \%$ lower than those in hotels or guesthouses. The platform has grown very rapidly in the last few years and has been used by millions of tourists (Guttentag et al., 2018).

In Czech Republic, Airbnb's offer consists mostly of apartments or separate rooms in central areas of larger cities. The platform nevertheless also operates in other places of tourist interest throughout the country.

Offering short-term rentals can be an alternative for people who live in apartments with at least one spare separate room which they however do not want to rent out permanently, because it is not always convenient for them to share the apartment with a roommate. Airbnb offers a choice of renting only during the working week and not on weekends, or vice versa. There are many options, and for the landlords, it is especially important to analyze them thoroughly. In some cases, renting through Airbnb is hugely advantageous, while at other times, it is preferable to rent the apartment to a suitable tenant.

In renting property through Airbnb, it is essential to set a goal and choose how to deal with the rental. Probably the most common scenario is becoming a host of one's own apartment. This involves cleaning, washing, ironing, and daily communication with guests and requires ability to communicate in foreign languages, organizational skills, being always online, responding to guests on time, and solving complications. In this way, profits are maximized, but so are the costs in terms of time and energy. In this case it is not possible to speak of passive income; renting absorbs holidays, weekends, and free time. Some responsibilities can be delegated, and in case of an emergency, it is possible to block availability of specific days in the Airbnb calendar, at the expense of one's profit.

People who do not have their own property but have the prerequisites/experience for running an Airbnb rental can rent the property of a friend/acquaintance, or a stranger, who will allow them to sublet the apartment on Airbnb in a lease agreement. This method has advantages and disadvantages - the host does not own the property, i.e., does not bear the burden of a mortgage or any other obligations arising from ownership. If they decide they no longer wish to host, the owner will find another tenant. The rent paid to the owner reduces the host's profit and its exact amount is significant, as is the overall calculation of the costs associated with renting. The host 
runs the risk of losing money in periods with few guests, as they still need to pay the rent to the owner.

Conversely, the most passive, and at the same time safest way to participate in the Airbnb platform is probably renting one's property to an Airbnb host. The owner receives $10 \%$ to $20 \%$ higher rental income than would be achieved with a long-term lease with no extra work. The host takes over all matters related to the apartment as well as the risks of renting. This involves any minor repairs, damages, handing over of keys, cleaning, and dealing with the guests. All these conditions can be incorporated in detail into the lease agreement.

Most authors state that the concept of sharing accommodation brings benefits not only to customers but also to cities by attracting more tourists and financial and economic benefits, but unfortunately also affects the quality of life of local citizens, affects housing markets and hotels (Rodas Vera and Gosling, 2017; Barata-Salgueiro, 2017; Horn and Merante, 2017; Gurran and Phibbs, 2017; Yrigoy, 2017; Wegmann and Jiao, 2017; Jenckova and Abrham, 2016). While most of the said authors state that the concept of shared economy has a disruptive effect on the performance of local accommodation, Horn and Merante (2017) argue that evidence on whether home sharing affects the housing market is quite limited. Even according to the article by Varma et al. (2016) there are significant differences between the types of customers who book Airbnb compared to those who book hotels.

\subsection{Tourism in Czech Republic}

After the Second World War, nationalization and the country's isolation from the Western world had the most significant influence on the development of tourism in Czech Republic. Organized tourism began to develop, and many accommodation facilities were built for trade unions or nationalized industry branches. Youth organizations and the $\mathrm{ROH}$ trade union association took part in organizing tourism activities. For political reasons, inhabitants of Czech Republic could only visit socialist countries. Apart from Czechia, then a part of the same country of Czechoslovakia, the most popular destinations were Yugoslavia, Bulgaria, Hungary, and the GDR. The opposite was also true, as the visitors to Czech Republic came mainly from these countries (Lauko et al., 2013).

The situation in tourism in Czech Repubic changed significantly after the fall of Communism in 1989. Positive changes occurred mainly in the political orientation of the country, its democratic development, its transition to a market economy. An important element in this period was the privatization of tourism facilities; this greatly increased competition in tourism, which was necessary to improve the level of services (Darcy, 2010).

Inflow of foreign investments in tourism took place in Czech Republic in connection with its accession to the European Union in 2004. Financial subsidies from pre-accession assistance under the PHARE program, later the European Structural and Investment Funds, were used to a large extent. (Lauko et al., 2013). Tourism in Czech Republic is currently marked mainly by the global economic crisis and insufficient use of the of the country's potential. The sector is of great importance for regional development: it creates jobs for the inhabitants of regions, brings finances, and raises the standard of living in regions (Senkova, 2013).

This paper aims to point out the impact of the Covid-19 pandemic on the sharing economy, specifically in the field of tourism and accommodation. The purpose is also to identify Covid19 related losses of accommodation facilities in Czech Republic which are part of the sharing economy through their use of the Airbnb platform. The results were compared to the hypothetical virus-free period of six months. The introduction defines the sharing economy and sums up the major scientific works related to the issue. The methodology section describes the method of database analysis of Airbnb accommodation. In the results section, we provide a 
comparison of the actual occupancy for the period of six months (February-July) with the sector significantly affected by Covid-19 and the expected occupancy without the pandemic. In the conclusion section, we provide an evaluation of the results.

\section{Methodology}

The method we used for analysis of 210 items is called one-way ANOVA. In practice, some studies are comparative. Such research aims to determine whether there are statistically significant differences between several basic sets. A statistical method called analysis of variance can be used to compare the means of these sets multiple times. The name of the method follows from the fact that the determination of whether the averages or the mean values differ significantly from each other is based on analysis of variances. For analysis of variance, the general designation ANOVA was introduced, which was created as an acronym from the English expression "ANalysis of Variance".

The correct use of analysis of variance requires the following assumptions:

1. Normality. The distribution of the sample means is normal.

2. Independence. The sample files are independent of each other.

3. Homoscedasticity. The variances of the base sets are equal (Chajdiak et al., 1994).

Before proceeding to the analysis, it is necessary to first verify whether these assumptions are met. Verification can be performed either numerically, via various tests, or graphically. It is recommended to use a combination of both.

One-factor analysis of variance examines the dependence of the observed feature $X$ (quantitative variable) on the factor $A$ (qualitative variable), which assumes at least two levels (categories). The dependence is demonstrated by a statistically significant difference in the averages of the observed characteristic $X$ between the sample sets, which are given by the individual levels of the factor $A$. If the factor has only two levels, then the one-factor analysis of variance will give the same result as the two-sample $t$-test. This is because a one-factor ANOVA represents an extension of the $t$-test to cases where it is necessary to compare more than two selections or groups (King et al., 2009).

The values for the one-factor analysis of variance are based on the values of the observed feature $X$ corresponding to the individual levels of the factor $A$. If the factor has $k$ levels, then we classify these values into $k$ groups. Let us denote the number of observations in the group $n i(i=1,2, \ldots, k)$ and the set $n_{1}+n_{2}+\ldots+n_{k}=N$. If the ranges of all groups are the same, we speak of a balanced model. Otherwise, it is an unbalanced model. The value of the observed $X$ measured at the level $i$ and when observing $j$ is denoted by $x_{i j}\left(j=1,2, \ldots, n_{i}\right)$ (Markechova et al., 2011).

The analysis of variance:

- the sum of the character values in the group:

$$
X_{i .}=\sum_{j=1}^{n_{i}} X_{i j}
$$

- the average in the group:

- the sum of all character values

$$
\overline{X_{l .}}=\frac{1}{n_{i}} \sum_{j=1}^{n_{i}} X_{i j}=\frac{X_{i}}{n_{i}}
$$

$$
X_{. .}=\sum_{i=1}^{k} \sum_{j=1}^{n_{i}} X_{i j}
$$


- and the overall average

$$
\bar{X}_{. .}=\frac{1}{N} \sum_{i=1}^{k} \sum_{j=1}^{n_{i}} X_{i j}=\frac{X_{. .}}{N}
$$

The meaning of the dot in the above formulas is "across all index values" (Budikova et al., 2010).

The mathematical model: The measured values $x i j$ are realizations of random variables $X i j$, which are governed by the model:

$$
X_{i j}=\mu_{i}+e_{i j}=\mu+\alpha_{i}+e_{i j}\left(i=1,2, \ldots, k, j=1,2, \ldots, n_{i}\right)
$$

Where:

$\mu$ is the total mean value of $X$,

$\alpha_{i}$ is the effect (influence) of the factor $A$ at the level $i$,

$e_{i j}$ is an independent random variable with distribution $N\left(0, \sigma^{2}\right)$.

The parameters $\mu, \alpha_{i}$ and $\sigma^{2}$ are unknown and their estimates are calculated using the least squares method. These are the following selection characteristics:

$$
\hat{\mu}=\bar{x}_{. .}, \quad \widehat{\alpha}_{l}=\overline{x_{l .}}-\overline{x_{. .}}, \quad \widehat{\sigma^{2}}=s_{r}^{2},
$$

Where:

$s_{r}^{2}$ is called residual scatter. It is defined in the following section.

We assume (Ramik, 2007):

$$
\sum_{i=1}^{k} \alpha_{i}=0
$$

If we have accepted the null hypothesis after performing a one-factor analysis of variance, then the conclusion is clear, and our analysis is complete. However, suppose we have rejected the hypothesis of equality of mean values. In such a situation, we are interested in answering the question of which pairs of mean values differ from each other. To answer this question, we use the so-called post-hoc multiple comparison tests. Many such tests exist, each with its own advantages and disadvantages.

\section{Results}

In this section we provide results from a database consisting of 210 accommodation facilities of the Airbnb platform in Czech Republic. Overall, we compared their original expectations of occupancy for a six-month period during the Covid-19 pandemic with the actual results from the same period.

\section{Table 1: Results from descriptives - expected data}

\section{Descriptives}

occupation rate 
Implications of the COVID-19 crisis for the sharing economy in tourism:

The case of Airbnb in the Czech Republic Authors: Vendula Fialova, Ivanka Vasenska

\begin{tabular}{lllllllll} 
& & & \multicolumn{3}{c}{$\mathbf{9 5 \%}$ Confidence Interval for } \\
& N & Mean & Std. Deviation & Std. Error & $\begin{array}{l}\text { Mean } \\
\text { Lower Bound }\end{array}$ & Upper Bound & Min & Max \\
\hline Home & 32 & 46,28 & 11,487 & 2,031 & 42,14 & 50,42 & 30 & 80 \\
Hostel & 40 & 61,43 & 13,578 & 2,147 & 57,08 & 65,77 & 40 & 85 \\
Cozy room & 27 & 61,56 & 15,263 & 2,937 & 55,52 & 67,59 & 40 & 85 \\
Loft & 21 & 62,81 & 14,323 & 3,126 & 56,29 & 69,33 & 40 & 84 \\
Apartment & 50 & 66,32 & 14,533 & 2,055 & 62,19 & 70,45 & 20 & 84 \\
Other & 40 & 38,53 & 28,203 & 4,459 & 29,51 & 47,54 & 0 & 90 \\
Total & 210 & 56,08 & 20,327 & 1,403 & 53,31 & 58,84 & 0 & 90 \\
\hline
\end{tabular}

Source: Own elaboration

Table 2: Results from descriptives - actual data

\section{Descriptives}

occupation rate

95\% Confidence Interval for

\begin{tabular}{llllllllll} 
& N & Mean & Std. Deviation & Std. Error & $\begin{array}{l}\text { Mean } \\
\text { Lower Bound }\end{array}$ & Upper Bound & Min & Max \\
\hline Home & 32 & 32,50 & 14,213 & 2,512 & 27,38 & 37,62 & 13 & 57 \\
Hostel & 40 & 45,95 & 6,547 & 1,035 & 43,86 & 48,04 & 33 & 56 \\
Cozy room & 27 & 28,52 & 10,009 & 1,926 & 24,56 & 32,48 & 14 & 48 \\
Loft & 21 & 51,71 & 12,370 & 2,699 & 46,08 & 57,34 & 31 & 70 & 60 \\
Apartment & 50 & 38,70 & 13,047 & 1,845 & 34,99 & 42,41 & 20 & 62 & 60 \\
Other & 40 & 44,35 & 11,229 & 1,775 & 40,76 & 47,94 & 22 & 13 & 70 \\
Total & 210 & 40,20 & 13,367 &, 922 & 38,39 & 42,02 & & 13 \\
\hline
\end{tabular}

Source: Own elaboration

Based on the descriptives in Tab. 1 and Tab. 2 we can see the number of rentals of different categories, which does not change as the values (expected and real) were obtained from the same facilities.

Subsequently, the homogeneity of the data was tested (Tab. 3; Tab. 4). Levene's statistic was used to test for homogeneity variances. Based on the results, non-significant results were obtained, which means that there is variance present.

Table 3: Homogeneity - expected data

\begin{tabular}{llll}
\hline Levene Statistic & df1 & df2 & Sig. \\
\hline 18,118 & 5 & 204 &, 100 \\
\hline
\end{tabular}

Source: Own processing

Table 4: Homogeneity - actual data

\begin{tabular}{llll}
\hline Levene Statistic & df1 & df2 & Sig. \\
\hline 7,533 & 5 & 204 &, 064 \\
\hline
\end{tabular}

Source: Own processing

The overall ANOVA is in both cases significant at the .000 level (Tab. 5; Tab. 6). 
Table 5: ANOVA - expected data

\begin{tabular}{|c|c|c|c|c|c|}
\hline \multicolumn{6}{|l|}{ ANOVA } \\
\hline \multicolumn{6}{|l|}{ occupation rate } \\
\hline & Sum of Squares & df & Mean Square & $\mathbf{F}$ & Sig. \\
\hline Between Groups & 23545,777 & 5 & 4709,155 & 15,295 &, 000 \\
\hline Within Groups & 62809,004 & 204 & 307,887 & & \\
\hline Total & 86354,781 & 209 & & & \\
\hline
\end{tabular}

Source: Own elaboration

There is a statistically significant difference between the levels of the independent variable but if we look at the post hoc test it is not possible to identify the differences. If there is homogeneity of variances, no further testing is required.

Table 6: ANOVA - actual data

\begin{tabular}{llllll}
\hline ANOVA & & & & & \\
\hline occupation rate & Sum of Squares & df & Mean Square & F & Sig. \\
& 10489,669 & 5 & 2097,934 & 15,936 &, 000 \\
Between Groups & 26856,526 & 204 & 131,650 & & \\
Within Groups & 37346,195 & 209 & & \\
Total & & & &
\end{tabular}

When we look at Tab. 7, we can see the differences between the different types of rentals. For example, for the Home-Hostel relationship, there is a statistically significant dependence of .000. There is therefore a statistically significant difference in occupancy rate between the Home and Hostel categories. On the contrary, the smallest statistically significant difference is between the categories Home-Cozy room.

Table 7: Post hoc tests, Multiple Comparisons - actual data

\section{Multiple Comparisons}

Dependent Variable: occupation rate

Tukey HSD

\begin{tabular}{|c|c|c|c|c|c|c|}
\hline & & & & & $95 \%$ & idence \\
\hline $\begin{array}{l}\text { (I) Property } \\
\text { type }\end{array}$ & (J) Property type & $\begin{array}{l}\text { Mean Difference } \\
\text { (I-J) }\end{array}$ & Std. Error & Sig. & $\begin{array}{l}\text { Interval } \\
\text { Lower }\end{array}$ & Upper \\
\hline & & & & & Bound & Bound \\
\hline & Hostel & $-13,450^{*}$ & 2,721 & ,000 & $-21,28$ & $-5,62$ \\
\hline & Cozy room & 3,981 & 2,998 & ,769 & $-4,64$ & 12,61 \\
\hline Home & Loft & $-19,214^{*}$ & 3,222 & ,000 & $-28,48$ & $-9,94$ \\
\hline & Apartment & $-6,200$ & 2,598 & ,166 & $-13,67$ & 1,27 \\
\hline & Other & $-11,850^{*}$ & 2,721 & ,000 & $-19,68$ & $-4,02$ \\
\hline & Home & $13,450^{*}$ & 2,721 & , 000 & 5,62 & 21,28 \\
\hline & Cozy room & $17,431^{*}$ & 2,858 &, 000 & 9,21 & 25,65 \\
\hline & Loft & $-5,764$ & 3,092 &, 427 & $-14,66$ & 3,13 \\
\hline & Apartment & $7,250^{*}$ & 2,434 & 038 & ,25 & 14,25 \\
\hline
\end{tabular}


Implications of the COVID-19 crisis for the sharing economy in tourism:

The case of Airbnb in the Czech Republic Authors: Vendula Fialova, Ivanka Vasenska

\begin{tabular}{|c|c|c|c|c|c|c|}
\hline & Other & 1,600 & 2,566 & ,989 & $-5,78$ & 8,98 \\
\hline \multirow{5}{*}{ Cozy room } & Home & $-3,981$ & 2,998 & ,769 & $-12,61$ & 4,64 \\
\hline & Hostel & $-17,431^{*}$ & 2,858 & ,000 & $-25,65$ & $-9,21$ \\
\hline & Loft & $-23,196^{*}$ & 3,338 & ,000 & $-32,80$ & $-13,59$ \\
\hline & Apartment & $-10,181^{*}$ & 2,740 & ,004 & $-18,07$ & $-2,30$ \\
\hline & Other & $-15,831^{*}$ & 2,858 & ,000 & $-24,05$ & $-7,61$ \\
\hline \multirow{5}{*}{ Loft } & Home & $19,214^{*}$ & 3,222 & ,000 & 9,94 & 28,48 \\
\hline & Hostel & 5,764 & 3,092 &, 427 & $-3,13$ & 14,66 \\
\hline & Cozy room & $23,196^{*}$ & 3,338 & ,000 & 13,59 & 32,80 \\
\hline & Apartment & $13,014^{*}$ & 2,984 & ,000 & 4,43 & 21,60 \\
\hline & Other & 7,364 & 3,092 &, 168 & $-1,53$ & 16,26 \\
\hline \multirow{5}{*}{ Apartment } & Home & 6,200 & 2,598 & ,166 & $-1,27$ & 13,67 \\
\hline & Hostel & $-7,250^{*}$ & 2,434 & ,038 & $-14,25$ &,- 25 \\
\hline & Cozy room & $10,181^{*}$ & 2,740 & ,004 & 2,30 & 18,07 \\
\hline & Loft & $-13,014^{*}$ & 2,984 & ,000 & $-21,60$ & $-4,43$ \\
\hline & Other & $-5,650$ & 2,434 & ,190 & $-12,65$ & 1,35 \\
\hline \multirow{5}{*}{ Other } & Home & $11,850^{*}$ & 2,721 &, 000 & 4,02 & 19,68 \\
\hline & Hostel & $-1,600$ & 2,566 & ,989 & $-8,98$ & 5,78 \\
\hline & Cozy room & $15,831^{*}$ & 2,858 & ,000 & 7,61 & 24,05 \\
\hline & Loft & $-7,364$ & 3,092 &, 168 & $-16,26$ & 1,53 \\
\hline & Apartment & 5,650 & 2,434 & ,190 & $-1,35$ & 12,65 \\
\hline
\end{tabular}

*. The mean difference is significant at the 0.05 level.

Source: Own elaboration

When we look at the result, illustrated using the means plots in SPSS, it shows the expected relationship between occupation rate and property type, based on expectations of individual hosts of various types of accommodation during the examined period.

Figure 1: Means Plot-expected data

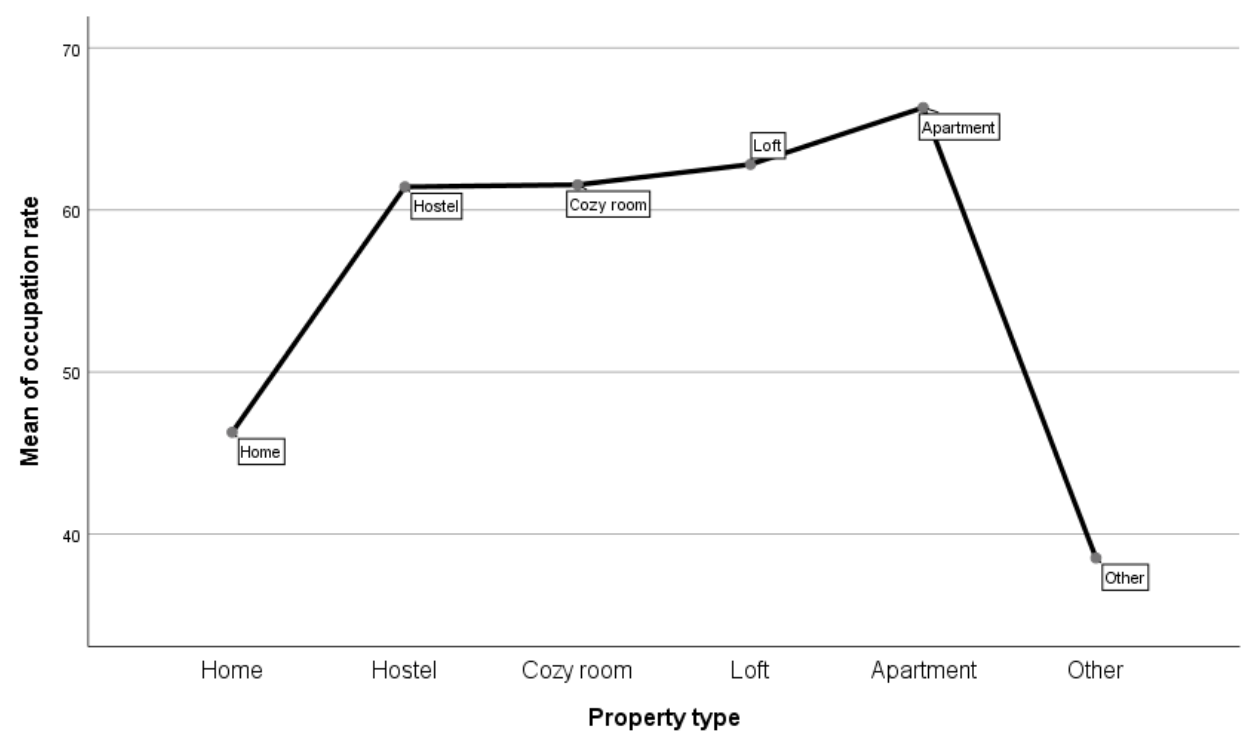

Source: Own elaboration 
However, the reality was different; travel was limited and accommodation facilities were closed. In some cases, the occupancy rate dropped to zero. No occupancy of any type of accommodation reached a rate higher than $55 \%$.

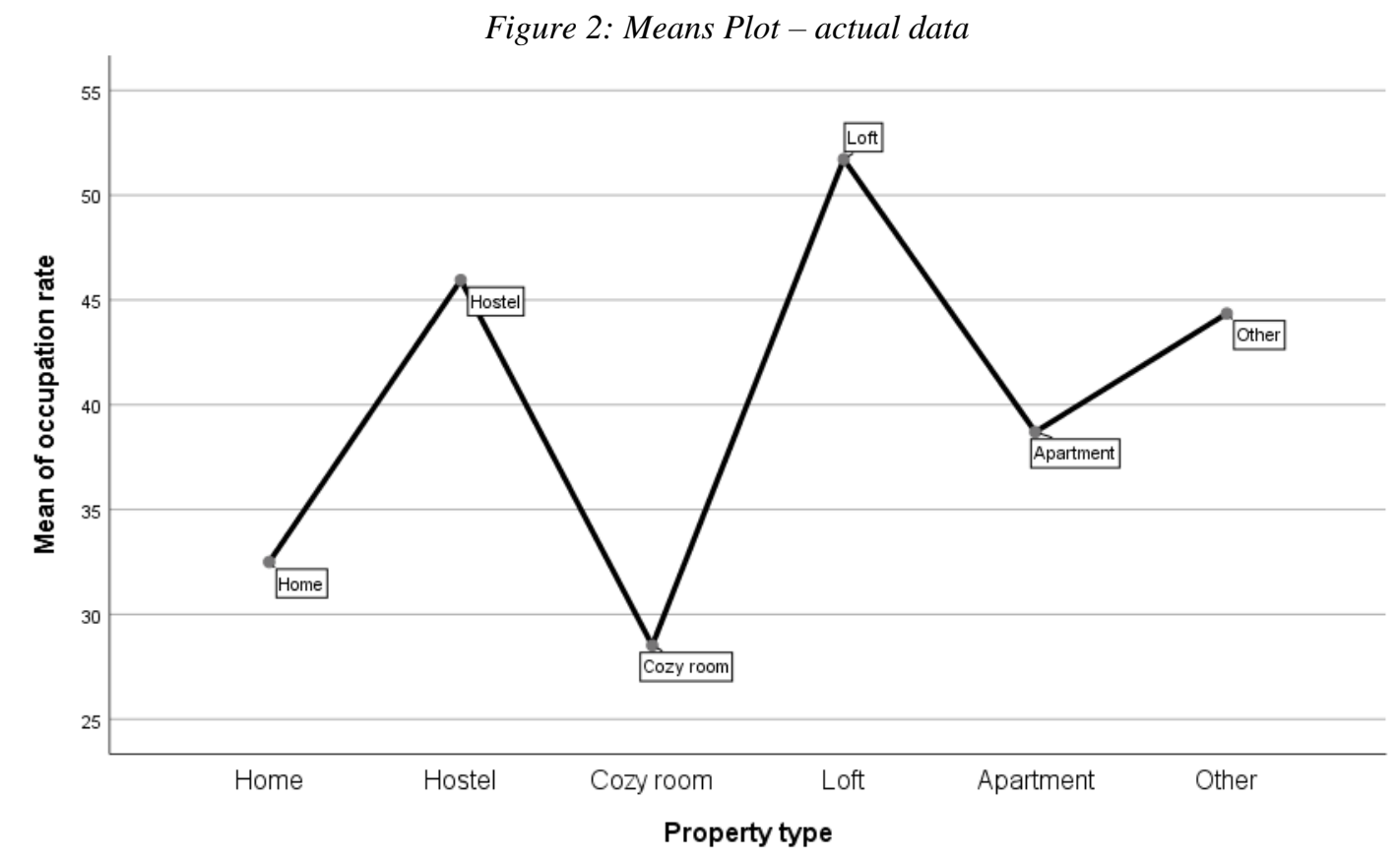

Source: Own elaboration

In total, we managed to obtain data from 210 accommodation facilities in Czech Republic, who provided us with their expected occupancy rates for the examined six-month period (February-July). At the same time, accommodations were categorized according to their type. All were available on the Airbnb platform. Subsequently, after six months, the hosts were contacted again and provided actual occupancy results for the past year.

\section{Discussions and Conclusions}

The area of the sharing economy most affected by the pandemic is accommodation. Hosts have lost their customers due to Covid-19 related travel restrictions. The measures taken to fight the virus have affected the management of companies in the sharing economy and the people who profit from it.

Hosts of the Airbnb platform feel the effects of radical restrictions even more acutely. As of this writing, international tourism is completely paralyzed, and tourists cancel their reservations around the world.

Initially, hosts could claim cancellation fees. But in early March, Airbnb decided that people from the most affected areas - China, South Korea, and Italy - could cancel their bookings without penalty. As of mid-March, this regulation applied to all customers worldwide. Property owners thus lost their sources of income in the coming weeks. In Czech Republic, the Airbnb rental business is not very widespread so far. Most of the affected hosts are in Bratislava, where less than a thousand properties are on offer. In other cities, the rental offer is significantly smaller.

The issue is currently very pressing and will be discussed for a long time, given the persistence of the pandemic and the related problems. It has strongly affected the sharing 
Implications of the COVID-19 crisis for the sharing economy in tourism:

The case of Airbnb in the Czech Republic Authors: Vendula Fialova, Ivanka Vasenska

economy, specifically the tourist accommodation sector, but also travel in general. Other related impacts are difficult to estimate. Many were forced to become more computer-savvy and adapt to communication over the internet. Airbnb is a platform for short-term leases. Most of its customers are tourists and travelers, including business travelers attending conferences. This will be an interesting topic to discuss in future articles. In any case, Covid-19 significantly affected the Airbnb business, and the consequences were worse than expected.

\section{References}

Akbar, Y. H., \& Tracogna, A. (2018). The sharing economy and the future of the hotel industry: Transaction cost theory and platform economics. International Journal of Hospitality Management, 71, 91-101.

Barata-Salgueiro, T. (2017). Short rentals in Lisbon. Scripta Nova-Revista Electronica De Geografia Y Ciencias Sociales, 21(578), 1-43.

Belk, R. (2014). You are what you can access: Sharing and collaborative consumption online. Journal of Business Research, 67(8), 1595-1600.

Dudikova, M., Kralova, M., \& Bohumil, M. (2010). Prưvodce základními statistickými metodami. Grada Publishing, a.s.

Camilleri, J., \& Neuhofer, B. (2017). Value co-creation and co-destruction in the Airbnb sharing economy. International Journal of Contemporary Hospitality Management, 29(9), 2322-2340.

Darcy, S. (2010). Inherent complexity: Disability, accessible tourism and accommodation information preferences. Tourism Management, 31(6), 816-826.

Edelman, B. G., \& Geradin, D. (2015). Efficiencies and regulatory shortcuts: How should we regulate companies like Airbnb and Uber. Stanford Technology Law Review, 19, 293.

Edelman, B., Luca, M., \& Svirsky, D. (2017). Racial discrimination in the sharing economy: Evidence from a field experiment. American Economic Journal: Applied Economics, 9(2), 1-22.

Gibbs, C., Guttentag, D., Gretzel, U., Yao, L., \& Morton, J. (2018). Use of dynamic pricing strategies by Airbnb hosts. International Journal of Contemporary Hospitality Management, 30(1), 2-20.

Gunter, U. (2018). What makes an Airbnb host a superhost? Empirical evidence from San Francisco and the Bay Area. Tourism Management, 66, 26-37.

Gurran, N., \& Phibbs, P. (2017). When tourists move in: how should urban planners respond to Airbnb? Journal of the American Planning Association, 83(1), 80-92.

Gutt, D., \& Herrmann, P. (2015). Sharing Means Caring? Hosts' Price Reaction to Rating Visibility. ECIS. Research-in-Progress Papers, No. 54.

Guttentag, D. A., \& Smith, S. L. (2017). Assessing Airbnb as a disruptive innovation relative to hotels: Substitution and comparative performance expectations. International Journal of Hospitality Management, 64, 1-10.

Guttentag, D., Smith, S., Potwarka, L., \& Havitz, M. (2018). Why tourists choose Airbnb: A motivation-based segmentation study. Journal of Travel Research, 57(3), 342-359.

Horn, K., \& Merante, M. (2017). Is home sharing driving up rents? Evidence from Airbnb in Boston. Journal of Housing Economics, 38, 14-24.

Chajdiak, J., Rublikova, E., \& Gudaba, M. (1994). Štatistické metódy v praxi. Statis.

Chen, Y., \& Xie, K. (2017a). Consumer valuation of Airbnb listings: A hedonic pricing approach. International Journal of Contemporary Hospitality Management, 29(9), 2405-2424.

Cheng, M. (2016). Sharing economy: A review and agenda for future research. International Journal of Hospitality Management, 57, 60-70.

Chen, Y., \& Xie, K. (2017b). Consumer valuation of Airbnb listings: A hedonic pricing approach. International Journal of Contemporary Hospitality Management, 29(9), 2405-2424.

Karlsson, L., Kemperman, A., \& Dolnicar, S. (2016). May I sleep in your bed? Getting permission to book accommodation in peer-to-peer accommodation networks. Annals of Tourism Research, 62, 1-12.

Krajcik, V., Kljucnikov, A., \& Rihova, E. (2019). Innovative Sharing Economy's Business Models in Tourism: Case of Airbnb in Prague. Marketing and Management of Innovations, 2, 108-117.

Jenckova, J., \& Abrham, J. (2016). Smart overbooking in the accommodation facilities in the Czech Republic. Journal of International Studies, 9(1).

Lauko, V., Tolmaci, L., Krizan, F., Gurnak, D., \& Cakoci, R. (2013). Geografia Slovenskej republiky: Humánna geografia. Geo-grafika.

Lee, D., Hyun, W., Ryu, J., Lee, W. J., Rhee, W., \& Suh, B. (2015). An analysis of social features associated with room sales of Airbnb. Proceedings of the 18th ACM Conference Companion on Computer Supported Cooperative Work \& Social Computing, 219-222. 
Li, J., Moreno, A., \& Zhang, D. J. (2016). Pros vs joes: Agent pricing behavior in the sharing economy.

Liang, S., Schuckert, M., Law, R., \& Chen, C.-C. (2017). Be a "Superhost": The importance of badge systems for peer-to-peer rental accommodations. Tourism Management, 60, 454-465.

Markechova, D., Tirpakova, A., \& Stehlikova, B. (2011). Základy štatistiky pre pedagógov. Nitra: uKF.

Priporas, C.-V., Stylos, N., Rahimi, R., \& Vedanthachari, L. N. (2017). Unraveling the diverse nature of service quality in a sharing economy: A social exchange theory perspective of Airbnb accommodation. International Journal of Contemporary Hospitality Management, 29(9), 2279-2301.

Puschmann, T., \& Alt, R. (2016). Sharing economy. Business \& Information Systems Engineering, 58(1), 93-99.

Ramik, J. (2007). Statistika: Pro navazující magisterské studium. Karviná: Slezská univerzita v Opavě.

Senkova, A. (2013). Analysis of development of tourism and hotel business in Slovakia after year 1989. Mladá veda/Young Science, 1(2), 29-38.

Tussyadiah, I. P., \& Pesonen, J. (2016). Impacts of peer-to-peer accommodation use on travel patterns. Journal of Travel Research, 55(8), 1022-1040.

Varma, A., Jukic, N., Pestek, A., Shultz, C. J., \& Nestorov, S. (2016). Airbnb: Exciting innovation or passing fad?. Tourism Management Perspectives, 20, 228-237.

Vaughan, R., \& Daverio, R. (2016). Assessing the size and presence of the collaborative economy in Europe. Publications Office of the European Union.

Vera, L. A. R., \& de Sevilha Gosling, M. (2017). Sharing economy in tourism: A theoretical discussion about collaborative consumption and sharing/economia compartilhada no turismo: Uma discussao teorica sobre o consumo colaborativo e o compartilhamento/economia compartida en turismo: Una discusion teorica sobre el consumo colaborativo y el compartir. Revista Eletronica de Estrategia e Negocios, 10(1), 226-252.

Yrigoy, I. (2017). Airbnb in Menorca: A new form of touristic gentrification? Distribution of touristic housing dwelling, agents and impacts on the residential rent. Scripta Nova-Revista Electrónica de Geografía y Ciencias Sociales, 21(580).

Wegmann, J., \& Jiao, J. (2017). Taming Airbnb: Toward guiding principles for local regulation of urban vacation rentals based on empirical results from five US cities. Land Use Policy, 69, 494-501.

Wu, J., Ma, P., \& Xie, K. L. (2017). In sharing economy we trust: The effects of host attributes on short-term rental purchases. International Journal of Contemporary Hospitality Management, 29(11), 2962-2976. 